\title{
8
}

\section{BUILDING BRAZIL'S PETROLEUMSCAPE ON LAND AND SEA}

\section{Infrastructure, Expertise, and Technology}

\section{Drielli Peyerl}

For centuries, Brazil served colonial actors as a commodity exporter-mainly of minerals and sugarcane. In the case of petroleum, the country has taken a different path. Early on, the government considered petroleum its best chance for achieving energy self-sufficiency. Its plans, however, were not quickly realized: it took a long time before petroleum was discovered in the territory and additional delays resulted from dependence on imported technologies, limited knowledge of the territory's geology, and a lack of qualified Brazilian technicians. To achieve self-sufficiency in oil production, the Brazilian government cultivated its know-how and trained its own workforce. Brazil's oil history demonstrates how flows of petroleum and the finances related to it can shape a landscape and a society. It also shows that the petroleumscape, once established, involves a feedback loop that brings corporate and public actors together to promote additional petroleum extraction, refining, and use. ${ }^{1}$ Once oil was discovered in Brazil, the oil industry developed quickly, which led to the construction of roads, housing, an education system, and many changes to the landscape and local infrastructure that were widely perceived as improvements.

The emergence of the petroleumscape in South America reflected both national interest and the spread of the first petroleumscape that expanded from the US throughout the American continent (see Hein and Lessoff, this volume). Besides that, nationalist movements and the development of the oil industry in other South American countries accelerated the formation of Brazilian national policies that pursued domestic oil extraction and refining. In the case of Argentina, Yacimientos Petroliferos Fiscales was founded in 1922, and in Bolivia, the state founded the company Yacimientos Petroliferos Fiscales Bolivianos at the end of 1936. The Bolivian government expropriated the activities related to oil exploration and refining that were being conducted by the US company Standard Oil. ${ }^{2}$ In Brazil, the federal government commanded by Presidente Getúlio Vargas created the National Petroleum Council (Conselho Nacional do Petróleo or CNP) in 1938, nationalizing the oil industry even before oil's discovery - a unique case in the history of the continent. In 1939, the first oil well was discovered in Brazil, in the Lobato neighborhood of Salvador City, in the state of Bahia. The discovery dramatically changed Salvador, leading to rapid population growth, 
mainly from people arriving in search of work. On a national level, the discovery encouraged oil research in other regions and the establishment of refineries. Until 1953, the CNP focused on achieving industrialization, conducting oil research, discovering new sources of oil, and eliminating foreign capital pressures from the oil sector. ${ }^{3}$

The Brazilian petroleumscape is unusual for at least two reasons. It was built as part of a national project over a century and it encompasses all aspects of spatial and social development, including education. This comprehensive approach became possible when national control was established over petroleum. In 1953, the federal government created the company Petróleo Brasileira S.A., abbreviated as Petrobras, and charged it with oil research as well as the mining, refining, trading, and transporting of oil from wells or shale from its derivates. ${ }^{4}$ Petrobras became a state petroleum monopoly and started to invest in an extensive exploration program in order to find large quantities of oil in the territory. ${ }^{5}$ As a national entity controlling both oil and urban planning, Petrobras also served as a tool for industrial development. The growing petroleumscape included not only refineries and office buildings, but hospitals, grocery stores, and schools. Many jobs were created at different levels of operation, including those for drillers, blade operators, heavy truck drivers, dynamite load handlers, aerial photo interpreters, designers, mechanics, seismograph operators, geologists, and paleontologists. ${ }^{6}$ As Petrobras transformed from an integrated corporation to a major offshore operator, its growth brought benefits to Brazilians who came to support the further development of the industry. The scale of its operations and the intersection of different interests also meant that Petrobras become one of the world's biggest exporters, arousing the interest of investors in other countries. ${ }^{7}$

This chapter explores three stages in the development of the Brazilian petroleumscape (Figure 8.1) in three distinct regions. It first considers Petrobras' activities in the Recôncavo basin, especially in Salvador, Bahia, where infrastructure construction laid the foundation for spatial development and served as an incentive for domestic research and education in the field of oil exploration. Then, it considers the petroleumscape's extension to the hinterland, the Amazon basin, Nova Olinda do Norte, in the state of Amazonas, a region considered suitable for oil exploration due to the presence of massive asphalt deposits in the neighboring country of Venezuela. Finally, this chapter considers the coast, where pre-salt layers (geological formations on the continental shelves) were discovered. Each of these cases involves onshore and offshore exploration and transnational exchanges between international companies, foreign and Brazilian professionals, and CNP/Petrobras. Each case reveals different patterns of investment; however, the national aim in each was to develop the country by means of petroleum.

\section{Building the Brazilian Petroleumscape as a Political and National Project}

As consumption of fuel for lighting, industry, and mobility increased in the second half of the nineteenth and the beginning of the twentieth century, countries around the world started to look for petroleum sources. Brazil's scale (8.516 million $\mathrm{km}^{2}$ ) and the exceptional economic, geographical, and environmental diversity of its twenty-six states were not initially conducive to oil exploration. The search for oil in the country started at the end of the nineteenth century. The first deep drilling for oil was reported in 1897 in the municipality of Bofete, in the state of São Paulo; however, sulfurous water was found. The historical lack 


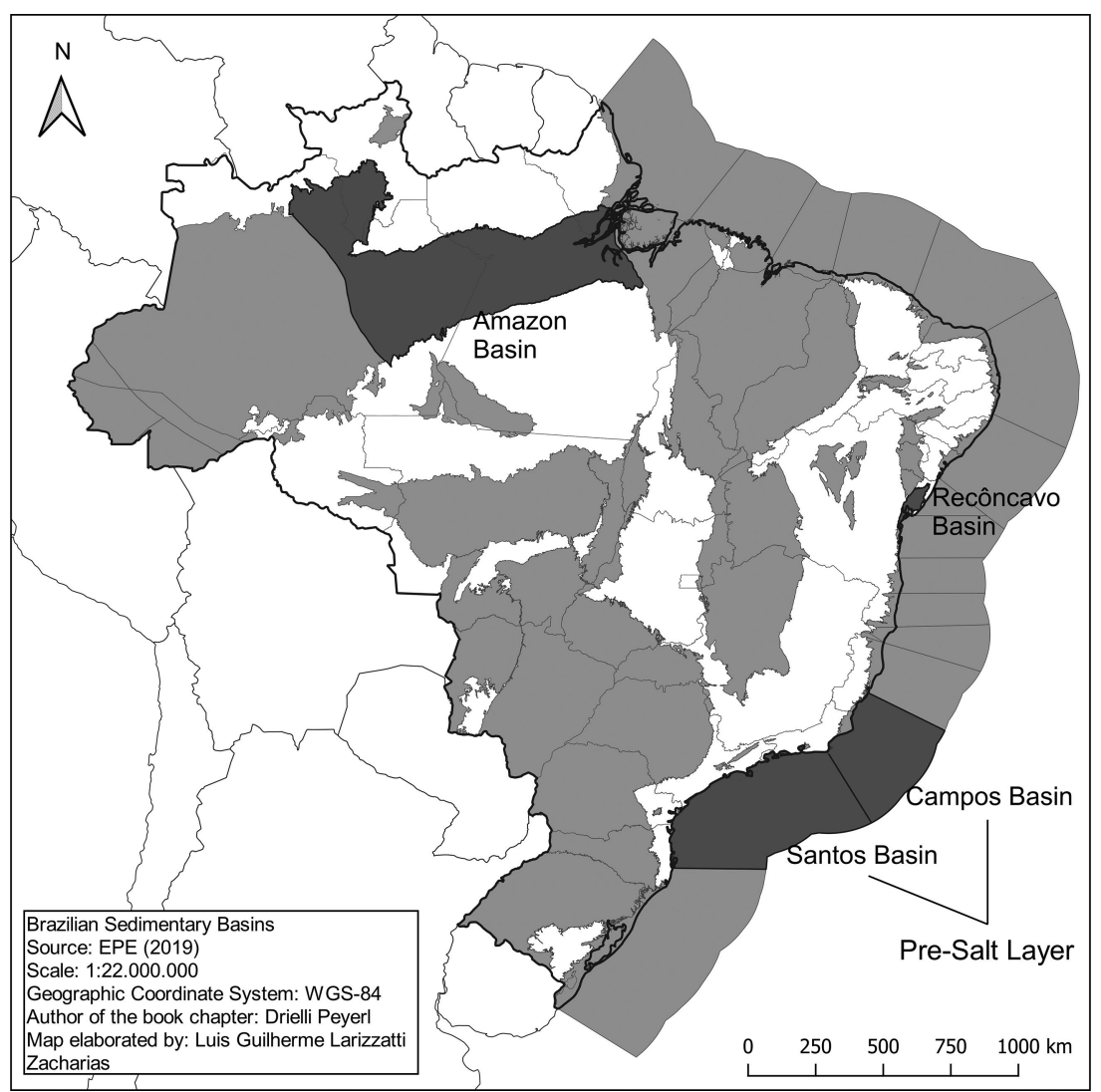

FIGURE 8.1 Map of the Brazilian sedimentary basin. Source: Drielli Peyerl; map drawn by Luis Guilherme Larizzatti Zacharias.

of geological knowledge of the territory, limited technology, and a shortage of professionals further impeded petroleum development. ${ }^{8}$

In the beginning of the twentieth century, instead of focusing on petroleum exploration, the Brazilian government invested mainly in the search for coal in its territory. ${ }^{9}$ In 1904, the Commission of Studies on the Stone Coal Mines of Brazil (Comissão de Estudos das Minas de Carvão de Pedra do Brazil) was created and supported by the Brazilian government. This commission, led by the North American geologist Israel Charles White (1848-1927), carried out the first coal surveys in southern Brazil. In 1908, two years after the end of the commission, White published a report that suggested the use of new techniques such as briquette for the use of domestic coal. ${ }^{10} \mathrm{He}$ also wrote two pages about the petroleum potential of the territory in response to countless questions from the government about the probability of finding oil there. He judged the possibilities low of discovering oil in commercial quantity in any part of southern Brazil, except in lands of the so-called Devonian era of the Amazon. ${ }^{11}$ At that point, the dream to find oil in Brazil became more distant. In fact, the repercussions of White's report discouraged national and international investments in the oil sector for many years. 
In the first decades of the twentieth century, other countries in South America also explored their territories for oil. By 1915, Venezuela had shown great promise as a major oil producer and had reaped the fruits of its early research. Its success yielded significant benefits for the careers of many geologists as well as funds that were used to rebuild the capital, Caracas. ${ }^{12}$ The discovery of oil in Venezuela raised the probability of oil in the Amazon basin in Brazil. An impressive number of oil drillings followed, beginning in 1919 with the Geological and Mineralogical Survey of Brazil; but they were also unsuccessful. ${ }^{13}$ Beginning in 1930, Brazil began transitioning from an agricultural economy to an industrial one, increasing the need for petroleum. ${ }^{14}$ Initially, the largest investments in the building of roads occurred in the south and southeast regions and in big urban centers such as Rio de Janeiro. ${ }^{15}$ The government pursued a more aggressive policy in the transport sector, gradually replacing the use of coal with gasoline and diesel. However, the lack of supply resulted in dependence on oil imports, mainly from the US.

The early growth of the petroleum industry in the US made US companies key players in developments in other parts of the world (see Hein, this volume). In the 1930s, the development of geophysics in US oil exploration revolutionized the search for oil in Brazil. Geophysical works executed by a North American company, United Geophysical, contributed to the first discovery of oil fields in the country, in the Reconcavo basin in $1939 .{ }^{16}$ The North American companies provided technology and professionals to explore the territory. They had prior experience in oil exploration and specifically in using geophysical surface methods, such as seismic and electrical methods.

The presence of foreign companies in Brazil was one of the reasons that in 1938, the Brazilian government created the CNP. After that, Brazil pursued a very strong national policy and the CNP decided to invest in developing the country's own expertise. The exploration and refining of petroleum resulted in disputes between nationalists and entreguistas (those who supported opening the sector to external capital). ${ }^{17}$ This conflict culminated in a campaign promoted by nationalists with the slogan "The petroleum is ours" (O petróleo é nosso), which advocated for national control over oil. ${ }^{18}$ All these factors led to the creation of one of the largest oil companies in the world, Petrobras, in the 1950s.

\section{Changing the Landscape with the Search for and the Discovery of Oil in Brazil}

The search for oil-even when unsuccessful-drove the development of the country, of both its institutions and its infrastructure. In January 1939, with the discovery of the first oil well in Salvador, all the petroleum deposits in the region "within a radius of 60 kilometers of Well 163 (the discovery well), were made a national reserve; exploration of the entire area was reserved to the CNP." ${ }^{19}$ Politicians used CNP's discovery of oil in Lobato as a symbol of wealth and self-sufficiency about to be achieved (Figure 8.2). Tremendous change took place in regions where the possibility of finding oil was favorable.

After four years of active exploration in the Lobato region, seventeen oil wells were explored (seven with petroleum, ten dry). All the oil wells were subcommercial, meaning that they did not produce oil in the quantity necessary for it to be considered economically viable. ${ }^{20}$ In 1941, Brazil's first commercially viable oil field was discovered, in the municipality of Candeias, also in Bahia. After this discovery, CNP focused on developing and applying geophysics methods in the attempt to find other oil fields in Bahia, specifically in 


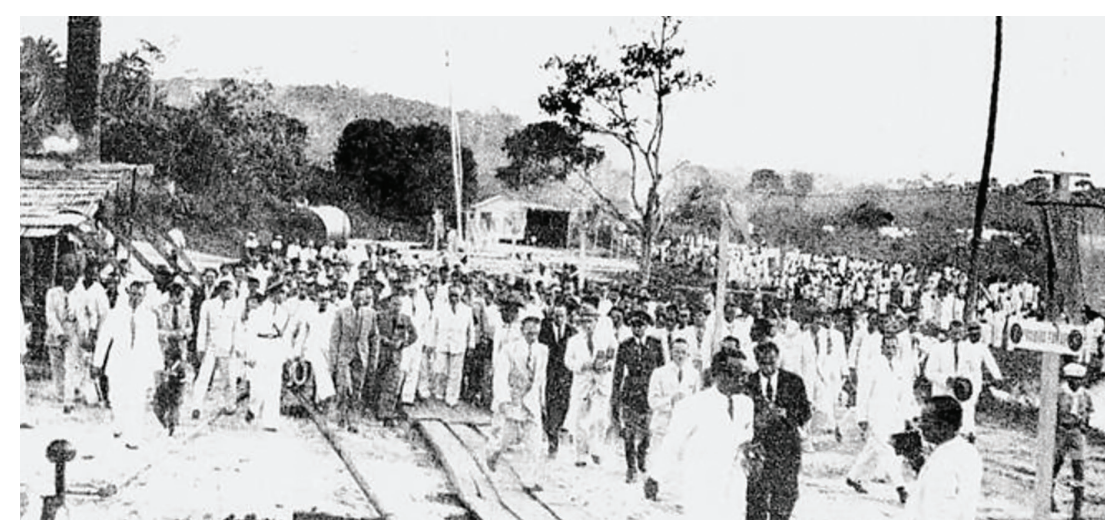

FIGURE 8.2 Visit of President Getúlio Vargas to the exploration fields on the Recôncavo Basin, Bahia, in October 1940. Source: “A excursão presidencial ao Norte - Bahia”, December 1940, p. 31. National Library of Brazil.

the Recôncavo basin. ${ }^{21}$ In the 1940 s, directly related to local oil exploration, a process of transformation started in the city when banks and import and export offices were established in Salvador.

In some cities where basic infrastructure was lacking-particularly in the Brazilian northeast, where CNP was searching for oil, and in the main economic centers in the states of São Paulo and Rio de Janeiro-CNP also invested in road building, urban construction, and the establishment of refineries. ${ }^{22}$ The federal government's support of CNP's exploratory activities triggered migration to the region, which contributed to urbanization, because it required a workforce from several sectors. Initially, conditions were considered inhospitable by CNP technicians, including those related to the health sector and urban infrastructure. Therefore, from 1940 to 1942, the work of CNP was restricted mainly to the area surrounding the discovery of the first oil well, known as the Reconcavo basin. The deficiency of the preliminary geological studies carried out by the CNP led to the hiring of foreign geologists and international companies.

Petroleum exploration created infrastructures that would shape the development of entire regions, even where oil was not found. In 1943, in Brazil's northeast, the work expanded to the Tucano basin (near the Reconcavo basin) and the drilling at the site resulted in highly sulfuric thermal water rather than oil. Later, this discovery led to the construction of hotels and attracted countless visitors, who believed the thermal water had health benefits. In the same period, when the CNP was active in the state of Maranhão, oil drilling led to the construction of roads, allowing access to these regions. Despite the results of surveys indicating that the wells were dry, the construction of a highway of $250 \mathrm{~km}$ was added to the state's transport system. In the case of the state of Rio Grande do Norte, some attempts to find oil resulted in the discovery of potable water wells in a region considered arid. ${ }^{23}$

The 1940s saw global and local problems for the development of the Brazilian oil industry mostly due to difficulties in importing petroleum. During World War II, the CNP found it difficult to import equipment from the US because of a lack of ships to carry it. ${ }^{24}$ Also, Brazil was getting most of the petroleum it consumed from the Caribbean island of Aruba through the Lago refinery. ${ }^{25}$ As tankers became unavailable as a result of the war, 
shortages ensued. ${ }^{26}$ Brazil started to ration the use of oil, mainly in Bahia and the southern part of the country, anticipating a shortage due to the war. At the end of August 1941, "some interior cities were partially blacked out, owing to fuel shortages; industry suffered." 27 Even with the problems brought about by the war, the construction of the hinterland infrastructure continued along with accelerated urbanization. In the process of industrialization, the southeast (the states of Espírito Santo, Minas Gerais, Rio de Janeiro, and São Paulo) experienced accelerated industrial development as a result of having borders on the ocean with ports that allowed access to international markets.

The growth of the refining industry and the search for new locations for oil exploration demanded more and more professionals and technicians and ultimately fueled domestic education and research. Throughout the 1950s, Petrobras collected geological data on Brazilian sedimentary basins to determine the possibility of finding oil. In most cases in Brazil, oil exploration resulted in dry wells, but it still contributed to the local development of cities due to the presence of professionals who required public services. A variety of people migrated to these places in search of income. In the case of the Recôncavo basin region, an oil industry was beginning to develop around the newly discovered fields. New cities formed in the state of Bahia that were economically based on oil exploration. In 1952, CNP invested in the creation of a sector that could train its own professionals, thus creating the Supervision Sector for Technical Improvement (SSAT), with the objective of generating its own technical and specialized labor. The Brazilian government had realized the importance of growing its own expertise. However, the lack of trained professionals in the area of geosciences with knowledge of sedimentary basins remained a problem for the CNP, which led to the hiring of foreign labor, despite being contrary to the nationalist project.

\section{Expanding the Petroleumscape into the Amazonas Region}

The initial success in developing spaces for and through petroleum exploration spurred attention to areas that demonstrated possibilities of finding oil, such as the Amazonian hinterland. In 1950, Brazil was an essentially rural country of the approximately 50 million inhabitants; almost 65 percent of the population lived in the countryside. ${ }^{28}$ The creation of a complex oil industry with all the necessary infrastructure would do a lot to change these numbers. ${ }^{29}$ In 1953, the federal government created Petrobras through Law No. 2.004, and the company gradually absorbed the activities of the CNP. One of Petrobras' goals was to organize a Department of Exploration, modeled on the most successful international companies. Its purpose was to find domestic sources of oil in great quantity. For this purpose, in 1954, Petrobras hired the North American geologist Walter Karl Link as chief superintendent of the Department of Exploration of Petrobras, with the responsibility of finding oil and ultimately of achieving Brazil's self-sufficiency.

According to Link, the conditions of the Brazilian oil industry were precarious at the time: there was a lack of equipment and qualified professionals and insufficient knowledge of Brazilian geology. These problems had existed since the first decades of the twentieth century. Petrobras invited Link to form the best exploration team money could buy. ${ }^{30}$ Link focused the activities of the Department of Exploration mainly on two initiatives:

a) development of the exploration program in Bahia, and b) investigation of the two biggest continental sedimentary basins in Brazil (the Solimões basin in the state of 
Amazonas due to its vast size, and the Paraná basin due to its geographical and economic importance). ${ }^{31}$

The state of Bahia was the scene of numerous investments by Petrobras and, prior to Petrobras' existence, the CNP. All this investment led to the economic development of the area. Before the arrival of Petrobras, Salvador and its region had a reputation as impoverished and infested with parasites and disease. ${ }^{32}$ The discovery of oil helped change this reputation. Petrobras' presence in Bahia contributed to urban development and transformed the region from agro-industrial to thoroughly industrial. The country's first government-owned refinery, the Landulpho Alves-Mataripe refinery in São Francisco do Conde, began operating in 1950. To serve the new industry, the company first sought to employ local fishermen and farmers to work both on the building of houses and on performing basic tasks at the refinery such as driving trucks.

The CNP and Petrobras then invested in training its employees to avoid future shortages. ${ }^{33}$ Workers involved in the construction of the Landulpho Alves-Mataripe refinery were housed in improvised shelters, initially built to hold 2,000 workers, and generally, these were temporary jobs. Some of the hired professionals, such as electricians, plumbers, and welders, sought accommodation in a nearby city, using company trucks to get back and forth. In order to improve the situation, Petrobras opted for the construction of prefabricated houses. Once the accommodations were completed, professionals started to bring their families to come and live in the city, depending on generators to power residential lighting. Leisure venues were also built, such as a club where it was possible to watch movies. ${ }^{34}$ Ultimately, such construction resulted in the growth of cities that formed a nucleus for the development of the oil industry in a national context (Figure 8.3).

The impact of oil exploration was not limited to land development. Brazil still depended substantially on oil imports. The construction of refineries benefited the national economy by importing crude oil, refining and transforming the product into derivatives such as gasoline and diesel. ${ }^{35}$ In 1950, CNP invested in the creation of the National Tanker Fleet (FRONAPE), which was intended to fulfill the country's transportation and storage needs pertaining to petroleum and related products, increasing the number of jobs in the city. ${ }^{36}$ FRONAPE maintained an office in Salvador, where it managed an active operation. On average, twelve domestic and foreign oil tankers arrived monthly, boosting the region's economy. FRONAPE was the first major initiative to solve the problem of shipping oil products in the country during this period. The investment in sectors of oil outside that of exploration also developed layers of the petroleumscape. ${ }^{37}$

From its inception, Petrobras was interested in exploring and developing the Amazon basin, beyond Bahia. Obstacles included transportation (vast rivers and wetlands), disease, geological problems imposed by intrusive rocks such as basalt flows and diabase, and inadequate logistical support. At the end of the 1950s, 60 percent of the exploration department's budget was invested in the Amazon basin. One of the areas it was exploring in the Amazon, specifically in Nova Olinda do Norte, was described as "a small river ravine with one or two huts." 38 In May of 1955, before oil was found in this location, the presence of drilling rigs and oil research led to the growth of a population nucleus around the exploration area. ${ }^{39}$

The research in Nova Olinda do Norte resulted only in a small amount of oil and the wells were abandoned (Figure 8.4). Petrobras continued with geological and geophysical investigations in the Amazon basin to find places where stratigraphic and structural conditions 


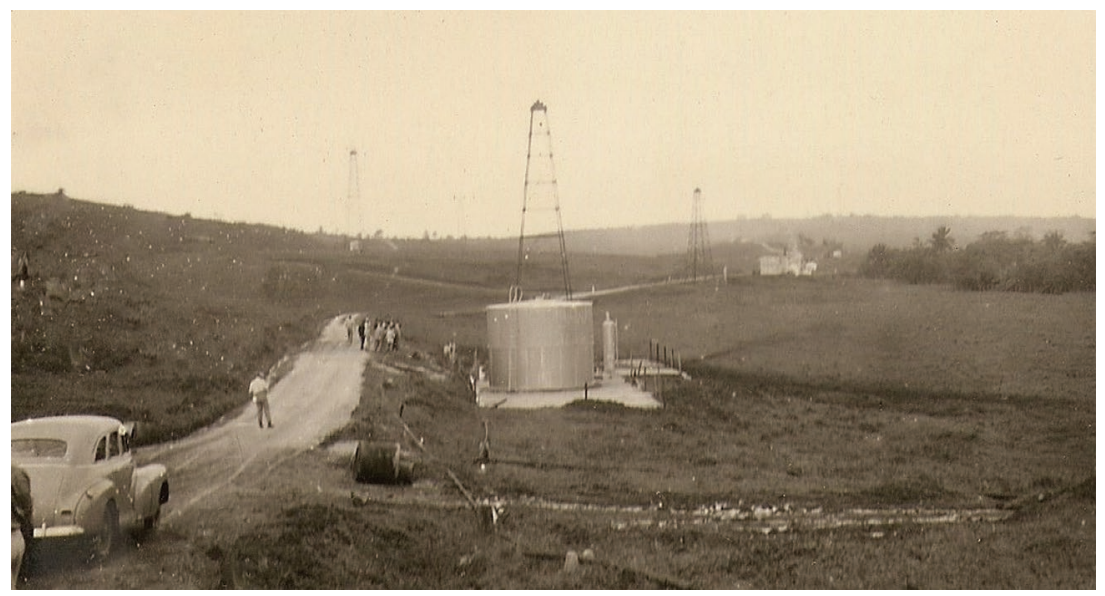

FIGURE 8.3 Oil exploration in Bahia in the early 1960s. Source: Frederico Waldemar Lange Archive (1911-1988), University of Ponta Grossa, Box 115.

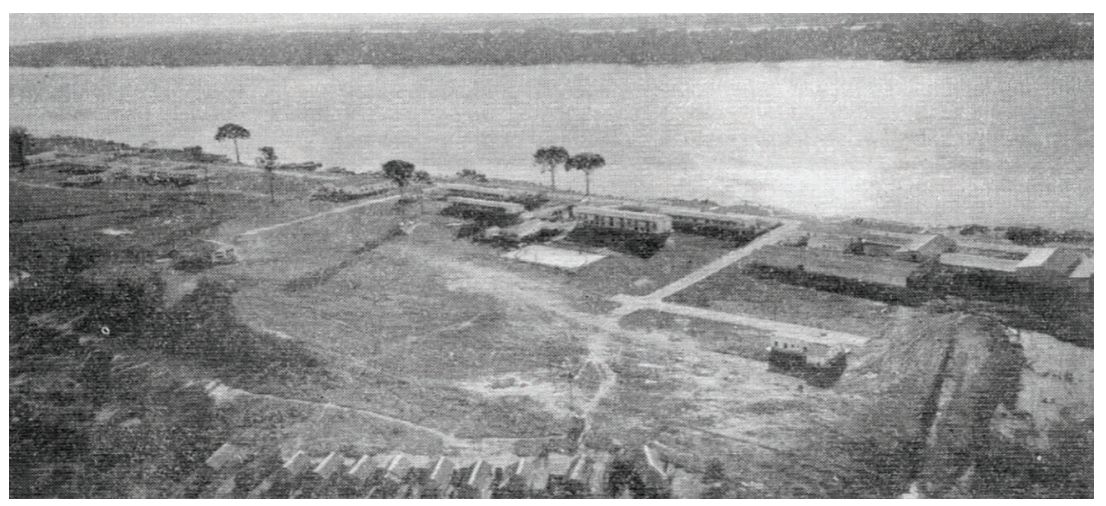

FIGURE 8.4 Nova Olinda do Norte, around the industrial facilities of Petrobras. Source: "Petrobras", 1961, p. 5. Frederico Waldemar Lange Archive (1911-1988), University of Ponta Grossa, Box 32 .

had a theoretically favorable association with oil accumulation. By the 1960s, the investments shifted away from exploratory research in the state of Amazonas. Reasons included the geographical situation, lack of storage, and problems involved in transporting oil to refineries.

An analysis of crude oil production between 1955 and 1960 in Brazil, comparing the US and Latin American countries (see Table 8.1), shows that the Brazilian oil industry was still on the rise at the time and Petrobras was still searching for oil wells. Even though they had not so far achieved great success, Petrobras continued to pursue national self-sufficiency and continued to invest in technology that could be used for oil exploration.

In addition to investing in that technology, starting in 1955, Petrobras created the Petroleum Improvement Center (CENAP), which operated a comprehensive program to prepare a specialized labor force, mainly focused on the exploration and industrialization of oil reserves. ${ }^{40}$ In 1957, Petrobras also approved guidelines for its Training and Improvement of Personnel Plan, an attempt to make up for the deficiencies of the Brazilian education system 
TABLE 8.1 World Crude Oil Production 1955/1959

\begin{tabular}{lccccc}
\hline Average Daily Production (Thousands of Barrels) & & & \\
\hline Countries/Year & 1955 & 1956 & 1957 & 1958 & 1959 \\
US & 6.807 & 7.151 & 7.170 & 6.709 & 7.042 \\
Venezuela & 2.157 & 2.457 & 2.779 & 2.606 & 2.768 \\
Colombia & 111 & 121 & 125 & 128 & 145 \\
Argentina & 84 & 87 & 93 & 98 & 120 \\
Brazil & 6 & 11 & 28 & 52 & 65 \\
Peru & 47 & 50 & 53 & 51 & 48 \\
Chile & 7.0 & 9.7 & 12 & 15.3 & 17.6 \\
Bolivia & 7.4 & 8.7 & 9.8 & 9.4 & 8.8 \\
Ecuador & 9.7 & 9.3 & 8.7 & 8.5 & 7.9 \\
\hline
\end{tabular}

Source: "Petrobras", 1961, p. 02. Frederico Waldemar Lange Archive (1911-1988), University of Ponta Grossa, Box 32 .

and linked to professional training for the petroleum industry. ${ }^{41}$ Through CENAP, courses were offered on such topics as refining, drilling for oil, petroleum geology, maintaining petroleum equipment, and petroleum engineering. ${ }^{42}$ In 1963, Petrobras created the Leopoldo Américo Miguez de Mello Research and Development Center (CENPES), which started operating in 1966. Taking a different approach than CENAP, CENPES focused its activities on a postgraduate program devoted primarily to the field of oil exploration and production. ${ }^{43}$

Petrobras longed to achieve national self-sufficiency, but while that goal remained elusive, the oil company invested in constructing refineries and many began operations. These included the Presidente Bernardes refinery in Cubatão, São Paulo, in 1955; the Duque de Caxias refinery in the state of Rio de Janeiro in 1961; the Gabriel Passos refinery in Betim, Minas Gerais, in 1968; the Alberto Pasqualini refinery in Canoas City, Rio Grande do Sul, also in 1968; the Paulina refinery in Paulínia, São Paulo, in 1972; the Auracária refinery in Auracária, Paraná, in 1977; and the Henrique Lage refinery in São José dos Campos, São Paulo, in $1980 .{ }^{44}$ The creation of refineries in different locations aided the Brazilian oil industry by reducing the cost of transporting oil products over long distances. It also contributed to local development in various regions of the country.

The continuous search for oil wells in Brazil, and investments, mainly in the refineries, contributed to modifications of the landscape throughout Brazil. For instance, Petrobras stoked national and international attention when it displayed its logo in competitions called Thousand Brazilian Miles. In São Paulo at the end of 1960, Petrobras participated in the event "V Thousand Brazilian Miles" (Figure 8.5), a competition intended to showcase the national vehicle and auto parts industry, but also the fuel produced by Petrobras refineries, which was used by participants at the event. This type of event showed the participation of Petrobras in social and cultural life.

Petrobras' exploration and construction of oil structures in the Amazon and its intervention in the landscape through huge investment and construction projects in other states, including petrochemical complexes such as Presidente Bernardes refinery in Cubatão, São Paulo, was the source of air pollution and other environmental problems. For many years, the World Health Organization considered Cubatão one of the most polluted cities in the world. In the 1980s, Cubatão became the largest petrochemical center in Latin America, and was referred to as "the Valley of Death" by news media and academic researchers 


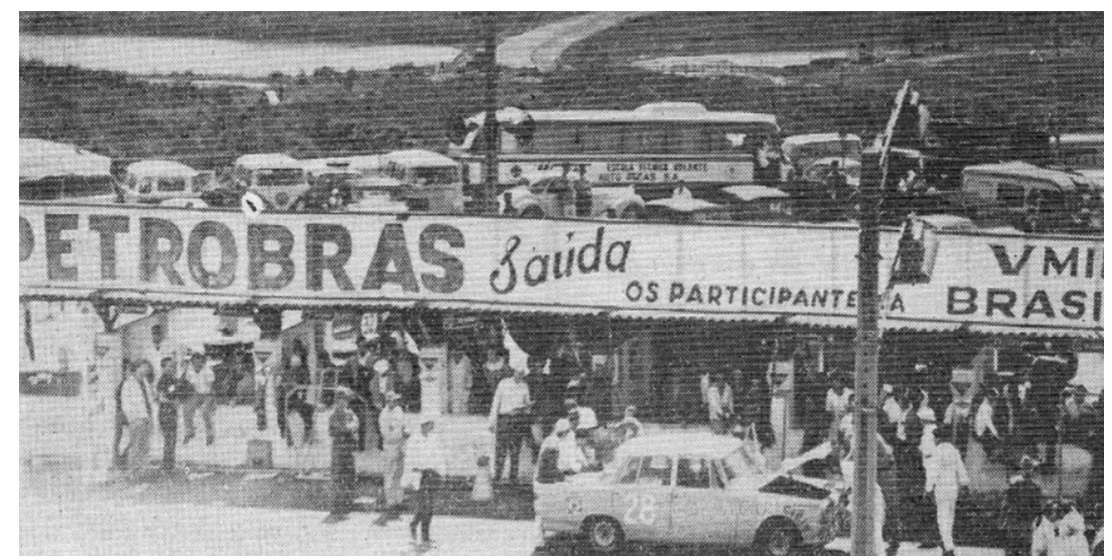

FIGURE 8.5 "V Thousand Brazilian Miles," with Petrobras gasoline. Source: Petrobras, 1961, p. 12. Frederico Waldemar Lange Archive (1911-1988), University of Ponta Grossa, Box 32.

because of its extreme levels of industrial pollution. ${ }^{45}$ Other sites had similar problems with environmental pollution stemming from the petrochemical industry, including the Camaçari refinery in Salvador. ${ }^{46}$ From 1980 to the present, Petrobras has been investing in programs to reduce pollution from industrial processes and to improve wastewater, air emission, and solid waste treatment systems. ${ }^{47}$

In the Amazon basin, in the 1980s, oil and natural gas exploration activities resumed due to the discovery of the largest proven onshore oil and natural gas reserve in Coari, $650 \mathrm{~km}$ from Manaus, capital of the state of Amazonas. The local economy began growing again and the liquefied petroleum gas produced in the region has since supplied the entire state and parts of other states. Petrobras has committed to limiting the negative environmental impact on the region, for example, by avoiding the creation of urban centers close to the exploration sites and trying to preserve the forest as much as possible. ${ }^{48}$

\section{Research and Development as Drivers of Offshore Exploration}

Brazil ultimately achieved oil self-sufficiency not from its efforts onshore, but through offshore exploitation. The experiences of the first two stages of petroleum exploration in Brazil had prepared the country for this endeavor. From 1968 on, Petrobras directed most of its work to petroleum research in the sea. The earlier expertise in infrastructural construction and research helped it take on new challenges involving the marine environment, including rocks below the ocean floor; the great distances between platforms and wells on the ocean floor and between platforms and the continent; and the invisibility of operations underwater. ${ }^{49}$ Offshore oil brought the royalties needed for investments in education, social and economic infrastructure, health, security, culture, sport, research, science and technology, civil defense, environment, and programs aimed at mitigating and adapting to climate change, for the treatment and social reintegration of drug addicts and programs to eradicate poverty. ${ }^{50}$

In 1968, the first offshore discovery was registered in a well drilled in shallow waters in the field of Guaricema in the Sergipe-Alagoas basin. Also in 1968, the first offshore drilling took place in the Campos basin, in the field of Garoupa, in the state of Rio de Janeiro. The following year saw discoveries at Campo de São Mateus and at Ubarana, both in the 
Potiguar basin in Espírito Santo. ${ }^{51}$ Meanwhile, international oil prices had begun to escalate, leading to the shocks of the 1970s and the opening of new exploratory frontiers worldwide, including the North Sea. ${ }^{52}$ At the end of the 1970s, in the words of historian Tyler Priest, "Petrobras forged even more boldly ahead with subsea technology in its Campos basin development, eventually becoming the leading innovator in this area." ${ }^{, 3}$

Moreover, by the 1970s, Petrobras had well-established operational bases, including an ancillary petroleumscape along the Brazilian coastline with offices and a complex and coordinated logistics system involving warehouses, workshops, ports, and airports in several capitals, known as "districts." 54 All these districts were controlled by the Petrobras headquarters in Rio de Janeiro, a place chosen for a number of reasons, including the presence of academic institutions such as the University of Rio de Janeiro and convenient transportation as well as a reputation for modernization and development. In addition, including investments in offshore activities, Petrobras started investing in other areas, such as with its creation of BR Distributing, a consumer sales division established in 1971; BRASPETRO, a division devoted to finding sources of oil abroad, established in 1972; Petrofertil, a fertilizer company established in 1973; and Interbras, devoted to international trade and services, established in $1976 .{ }^{55}$

The construction of the spatial petroleumscape was closely related to advances in geological technology. Discoveries took yet another step, when Petrobras went from a period of shallow water exploration (1965-1984) to a deep-water phase (1984-1997) taking advantage of new deep water technology. ${ }^{56}$ Since 1984 , the oil and gas industry has applied the new technology notably in the Campos basin, including new technologies such as 3D seismic exploration, which optimized time and costs from discovery to field development. ${ }^{57}$ In 1986 , Petrobras created the Program of Technological Training to explore offshore areas. Because of its numerous discoveries over the years, Petrobras became the international leader in deep-sea exploration technology. ${ }^{58}$

In 1997, after decades of Petrobras holding a petroleum monopoly, the New Petroleum Law was enacted (9478/97), regulating the oil sector in the country and creating the National Agency for Petroleum, Natural Gas and Biofuels (ANP). Both decisions started a new era for the Brazilian oil industry contributing to a more competitive oil sector market and openness for investment by international oil companies. Petrobras still constitutes an industry with a strong presence in some coastal cities, directly influencing the process of urbanization, the real estate market, and infrastructure due to the receipt of royalties.

By the mid-2000s, Brazil started to benefit from the scientific and technological infrastructure it had built for several decades. In 2006, the discovery of the pre-salt oil region (extending from the coast of Espírito Santo to Santa Catarina) made Brazil a net exporter of oil. ${ }^{59}$ Thus, a new pattern of interaction between Petrobras and its large foreign suppliers such as Shell had started, in relation to the development of technologies applicable to oil exploration in offshore area. ${ }^{60}$

\section{Three Regions, Three Time Periods, Three Petroleumscape Transformations}

Since the last century, the Brazilian government and society developed a network of integrated space connected to petroleum. These spaces involved, as Carola Hein has theorized, not just a physical landscape but a social imaginary and forms of citizen behavior. ${ }^{61} \mathrm{CNP}$ and Petrobras became a collective representation of Brazilian society associated with economic 
development and progress. Initially, oil was responsible for population growth, housing construction, and the development of basic services in Salvador. The construction of the refinery and universities changed the landscape of that city, bringing rapid economic development, including migration from rural to urban areas. Brazil's petroleumscape continued to be constructed by the state through education, the consolidation of a national oil industry, and the formation of its own skilled labor force. With the discovery of oil in pre-salt layers, self-sufficiency was achieved and even greater wealth was produced. Oil wealth-associated with ease, comfort, and freedom-brought problems as well as solutions.

The creation of Petrobras, a huge company intimately connected with the government and its financial and planning powers, established conditions not just for an extensive petroleumscape, but also for large-scale corruption. In 2014, after a long investigation by public prosecutors and the Federal Police of Brazil, Petrobras was found to have enabled "billions of dollars in kickbacks from large contracts paid by suppliers to executives of the oil company and politicians." 62 But even when associated with such illegality, it has managed to recover. Although the corruption charges weakened the confidence of many foreign investors, ${ }^{63}$ they did little to damage Brazilians' pride in the company. There is a tendency to see the problem as a matter of the inevitable dishonesty of politicians and of big business. Petrobras had and still has a role in various sectors in addition to petroleum and remains active in education, for example, through Petrobras University. Demonstrating concern regarding environmental and sustainability issues, Petrobras has invested in research on renewable energies and biofuels and $\mathrm{CO}_{2}$ reduction in upstream activities, including exploration, drilling, and extraction. ${ }^{64}$

Positive national sentiment has remained strong toward CNP and Petrobras also because of the countless attempts over the years to find onshore oil. Even before finding domestic sources of oil in sufficient quantity, the company worked to maintain the goodwill of consumers and citizens, spreading commerce around the country through gas stations and petroleum products, employing workers, and becoming an accepted part of everyday life. As a company, it has served as a model for other countries and, in Brazil and many other places, Petrobras and petroleum in general are associated with progress and development driven by national political decisions.

\section{Acknowledgments}

Drielli Peyerl is especially grateful for the financial support of grant process 2017/18208-8 and 2018/26388-9 from the São Paulo Research Foundation (Fundação de Amparo à Pesquisa do Estado de São Paulo [FAPESP]). The author gratefully acknowledges support from SHELL Brazil and FAPESP through the "Research Centre for Gas Innovation" (RCGI) (Fapesp Proc. 2014/50279-4), hosted by the University of São Paulo, and the strategic importance of the support given by ANP (Brazil's National Oil, Natural Gas and Biofuels Agency) through R\&D levy regulation.

\section{Notes}

1 Carola Hein, "Oil Spaces: The Global Petroleumscape in the Rotterdam/The Hague Area," Journal of Urban History 44, no. 5 (2018): 887-929.

2 Luciano Martins, Pouvoir et développement économique - formation et Evolution des structures politiques au Brésil (Paris: èditions Anthropos, 1976). 
3 Drielli Peyerl, The Oil in Brazil (Cham, Switzerland: Springer Nature Switzerland AG, 2019).

4 Brazil. Law n. 2.004, 3 October 1952, www.planalto.gov.br/ccivil_03/L2004.htm, accessed January 2013.

5 José Luciano de Mattos and Maria Ana Quaglino, A questão do petróleo no Brasil: uma história da Petrobrás (Rio de Janeiro: Fundação Getúlio Vargas, 1993).

6 Pedro de Moura and Felisberto Carneiro, Em busca do petróleo brasileiro (Ouro Preto: Fundação Gorceix, 1976).

7 Edmilson Moutinho dos Santos and Drielli Peyerl, "The Incredible Transforming History of a Former Oil Refiner into a Major Deepwater Offshore Operator: Blending Audacity, Technology, Policy and luck, from the 1970s Oil Crises up to the 2000s Pre-Salt Discoveries," in History, Exploration and Explotation of Oil and Gas, eds. Silvia F. de M. Figueirôa, Gregory Good, and Drielli Peyerl (Cham, Switzerland: Springer Nature Switzerland AG, 2019), 87-100.

8 Juarez Távora, Petróleo para o Brasil (Rio de Janeiro: José Olympio, 1955).

9 Peyerl, Figueirôa, Silvia, Moretto, Mouette, dos Santos, and Moutinho dos Santos, "The Problem of Domestic Supply of Fossil Fuels in Brazil," Oil-Industry History 18 (2018): 97-106.

10 Israel Charles White, Relatório Final: Comissão de Estudos das Minas de Carvão de Pedra do Brazil (Rio de Janeiro: Imprensa Nacional, 1908).

11 Ilmar Penna Marinho Júnior, Petróleo: política e poder - um novo choque do petróleo? (Rio de Janeiro: José Olympio, 1989).

12 Edgar Wesley Owen, Trek of the Oil Finders: A History of Exploration for Petroleum (Tulsa, OK: The American Association of Petroleum Geologists, 1975); Carola Hein, "Maurice Rotival: French Planning on a World-Scale (Part I)," Planning Perspectives 17, no. 3 (2002): 247-65; Carola Hein, "Maurice Rotival: French Planning on a World-Scale (Part II)," Planning Perspectives 17, no. 4 (2002): 325-44.

13 Peyerl, Oil in Brazil.

14 Sônia R. de Mendonça, "As bases do desenvolvimento capitalista dependente: da industrialização restringida à internacionalização," in História Geral do Brasil, ed. Maria Y. Linhares (Rio de Janeiro: Elsevier, 1990): 316-26.

15 Hamilton de M. Monteiro, “Da República Velha ao Estado Novo," in História Geral do Brasil, ed. Maria Y. Linhares (Rio de Janeiro: Elsevier, 1990).

16 Drielli Peyerl and Silvia Fernanda de Mendonça Figueirôa, "Applied Geophysics in Brazil and the Development of a National Oil Industry (1930-1960)," History and Technology 36 (2020): 1-22.

17 Gabriel Cohn, Petróleo e Nacionalismo (São Paulo: Difusão Européia do Livro, 1968).

18 Peyerl, Oil in Brazil.

19 Peter S. Smith, Oil and Politics in Modern Brazil (Canada: Macmillan Company of Canada Limited, 1976), 37.

20 M. da S. Pinto, Mário da Silva Pinto: depoimento [1987]; Interview (Rio de Janeiro: CPDOC/ FGV - SERCOM/Petrobrás, 1988).

21 Peyerl and Fernanda de Mendonça Figueirôa, "Applied Geophysics.”

22 Peyerl, Oil in Brazil.

23 Petrobras, A Petrobrás prepara o seu pessoal técnico: manual (Rio de Janeiro: Centro de Aperfeiçoamento e Pesquisa de Petróleo, 1957). Frederico Waldemar Lange Archive (1911-1988), Box 114.

24 Smith, Oil and Politics, 42.

25 Smith, Oil and Politics.

26 Ibid.

27 Ibid., 43.

28 de M. Monteiro, "Da República Velha ao Estado Novo."

29 André Ribeiro, Leopoldo - Os caminhos de Leopoldo Américo Miguez de Mello (Rio de Janeiro: Petrobras/CENPES, 2010).

30 Drielli Peyerl, Silvia F. M. Figueirôa, and Elvio Pinto Bosetti, "The North American Geologist Walter Karl Link and Oil Exploratory Research at Petrobras (1954-1960)," Earth Sciences History, 35 (2016): 387-98.

31 Ibid., 394.

32 M. da S. Pinto, Mário da Silva Pinto: depoimento [1987]. Interview (Rio de Janeiro: CPDOC/ FGV - SERCOM/Petrobrás, 1988).

33 Exploração na Bahia, report, Frederico Waldemar Lange Archive (1911-1988); Caixa 115, 1958.

34 Carlos E. P. Barreto, A saga do petróleo brasileiro: "a farra do boi" (NBL Editora, 2001). 
35 Drault Ernanny de Mello e Silva, A questão do petróleo (Rio de Janeiro: [not known], 1952).

36 Peyerl, Oil in Brazil.

37 Carola Hein, "Oil Spaces: The Global Petroleumscape in the Rotterdam/The Hague Area," Journal of Urban History 44 (5) (2018): 887-929.

38 Petrobras, Rio de Janeiro: VII, no. 179 (January 1, 1961): 4.

39 Ibid.

40 Alceu Pinheiro Fortes, CENAP - Petrobras: uma breve memória 1954-1964 (Rio de Janeiro: Petrobras, 2003).

41 Petrobras, A PETROBRÁS prepara o seu pessoal técnico: manual. Rio de Janeiro: Centro de Aperfeiçoamento e Pesquisa de Petróleo (1957), Frederico Waldemar Lange Archive (1911-1988). Box 114.

42 Antonio Seabra. Moggi, "Pessoal para o avanço Tecnológico a experiência da Petrobrás," Diário de Notícias Newspaper (Rio de Janeiro, Ed. 13840, December, 1967).

43 Peyerl, Oil in Brazil.

44 "Petrobras," www.petrobras.com.br/en/about-us/our-history/, accessed April 2018.

45 Daniel J. Hogan, "Population, Poverty, and Pollution in Cubatão, São Paulo," Geographia Polonica, no. 64 (1995): 201-24.

46 Tânia Franco, ed. Trabalho, Riscos Industriais e Meio ambiente: rumo ao desenvolvimento sustentável? (Salvador: EDUFBA, 1997).

47 “Petrobras," www.petrobras.com.br/en/about-us/our-history/, accessed April 2018.

48 P. V. Santana, "Dimensões espaciais de cidades amazonenses: do dinheiro do petróleo aos serviços públicos de educação," in Desenvolvimento regional no Brasil: políticas, estratégias e perspectiva, ed. A. M. Neto, C. N. Castro, and C. A. Brandão (Rio de Janeiro: Instituto de Pesquisa Econômica Aplicada - IPEA, 2017): 157-96.

49 José Mauro de Morais, Petróleo em águas profundas: uma história tecnológica da Petrobras na exploração e produção offshore (Brasília: Ipea and Petrobras, 2013).

50 Brazil. Law n. 12.734, November, 2012, http://www4.planalto.gov.br/legislacao/, accessed June 2020.

51 J. B. O. Neto and A. J. D. Costa, "A Petrobrás e a exploração de Petróleo offshore no Brasil: um approach evolucionário," Revista Brasileira de Economia, Rio de Janeiro 61, no. 1 (January/March, 2007): 95-109, 100.

52 Tyler Priest, Offshore Imperative - Shell Oil's Search for Petroleum in PostWar America (College Station: Texas A\&M University Press).

53 Ibid., 187.

54 Marco A. Pinheiro Machado, Pré-sal: a saga - A história de uma das maiores descobertas mundiais de petróleo (Porto Alegre: L\&M, 2018).

55 Cristovão Brito, A PETROBRAS e a gestão do território no Recôncavo Baiano (Salvador: EDUFBA, 2008).

56 C. H. L. Bruhn, A. C. C. Pinto, P. R. S. Johann, M. C. Salomão, and E. B. Freire, "Campos and Santos Basins: 40 Uears of Reservoir Characterization and Management of Shallow to Ultradeep Water, Post- and Pre-Salt Reservoirs - Historical Overview and Future Challenges," Offshore Technology Conference (24-26 October, Rio de Janeiro, Brazil, 2017).

57 Technology Petrobras (Petrobras, 2013), and R. Fainstein, A. Krueger, and W. U. Mohriak, "UltraDeepwater Seismic Plays Offshore Brazil - Future Drilling off Santos and Campos Basins," Interpretation (2019): 1-34.

58 J. B. O. Neto and A. J. D. Costa, "A Petrobrás e a exploração de Petróleo offshore no Brasil: um approach evolucionário," Revista Brasileira de Economia 61, no. 1 (January/March, 2007): 95-109, 100.

59 A. S. Magalhães and E. P. Domingues, "Blessing or Curse: Impacts of the Brazilian Pre-Salt Oil Exploration,” EconomiA 15 (2014): 343-62.

60 Andre Tosi Furtado, "Pré-sal, Desenvolvimento Industrial e Inovação," Revista Paranaense de Desenvolvimento 34, no. 125 (July/December 2013): 79-100, 92.

61 Hein, "Oil Spaces."

62 Renato Lima-de-Oliveira, "Corruption and Local Content Development: Assessing the Impact of the Petrobras' Scandal on Recent Policy Changes in Brazil," Extractive Industries and Society 2, no. 7 (2019): 274-82, 274.

63 Amelie Pedersen, "The Impact of Corruption on the Performance of State-owned Companies Case of Petrobras Brasil”" (MA thesis, Fundação Getulio Vargas Escola de Administração de Empresas De São Paulo, 2016).

64 Petrobras, http://www.petrobras.com.br/en/about-us/our-history/, accessed July 2020. 